\title{
Australian students' activity preferences, perceived physical risk and interest in vacationing in Japan
}

Journal of Vacation Marketing

2018, Vol. 24(4) 355-370

(C) The Author(s) 2017

Article reuse guidelines:

sagepub.com/journals-permissions DOI: $10.1177 / 1356766717736348$

journals.sagepub.com/home/jvm

(S)SAGE

\author{
Aaron Tkaczynski \\ University of Queensland, Australia \\ Hayato Nagai \\ Wakayama University, Japan \\ Sharyn R Rundle-Thiele \\ Griffith University, Australia
}

\begin{abstract}
The purpose of this study was to identify Australian students' activity preferences, perceived physical risk and interest in Japan as a vacation destination. Based on a sample of 422 Australian students, five activity factors were determined. These were labeled as cultural, outdoor, excitement, built attractions and personal. Australian students were extremely interested in vacationing in Japan and they generally perceived few physical risks of a Japanese vacation. Hygiene risk significantly contributed to variance in interest in vacationing in Japan. Four activity types significantly contributed to interest in travel to Japan and perceived physical risk did not mediate the activity preference and interest relationship. Theoretical and practical implications for this research are outlined and limitations and opportunities for future research are provided.
\end{abstract}

\section{Keywords}

Activity preferences, interest, Japan, perceived physical risk, vacation

\section{Introduction}

Student travel signifies a substantial, growing market to the global economy (Gardiner et al., 2013; Glover, 2011). It is estimated that by 2020 this market will represent 370 million travelers, which will inject US\$400 billion into the global economy (World Tourism Organization, 2016). In addition to providing destinations with financial injection, the student market is desirable to tourism marketers such as destination marketing organizations (DMOs) because of students being time rich (Thrane, 2016) and having increased mobility (de Wit et al., 2013). The World Youth Student and Educational Travel Confederation (2013) also argues that young travelers will often spend more than other tourists and are likely to return and give more value to the destination over their lifetime.

Destinations require superb attractions, accommodation and transport facilities to survive competitively (Enright and Newton, 2005; Morrison, 2013). While activities such as sightseeing and cultural entertainment may be universally recognized as popular activities at most destinations (Finsterwalder and Laesser, 2013; McKercher et al., 2002), tourism marketers need

\footnotetext{
Corresponding author:

Aaron Tkaczynski, University of Queensland, Cnr Blair Drive and Campbell St, St Lucia 4072, Brisbane, Queensland 4072, Australia.

Email: a.tkaczynski@uq.edu.au
} 
to determine the key attractions that will appeal to specific cohorts of tourists (e.g. segments) which may motivate them to travel.

Regardless of its competitive appeal, such as the attractive activities that they offer, a destination that may cause a tourist harm may serve as a major deterrent to destination visitation (Sönmez and Graefe, 1998). While the types of risks may vary, physical-related issues such as natural disasters (e.g. bush fires, tornadoes or hurricanes) (Nagai and Tkaczynski, 2014; Walters et al., 2015), participation in strenuous physical activities (e.g. skydiving, hiking and white-water rafting) (Beedie and Hudson, 2003; Carnicelli-Filho et al., 2010), or vacationing at a destination when a crisis such as a health outbreak (e.g. Ebola, swine flu) occurs (Fuchs and Reichel, 2011; Reisinger and Mavondo, 2005) represent important inhibitors to travel.

Consideration of the perceived physical risks along with appealing attractions and the interest in the destination is warranted when identifying whether a specific market (e.g. student tourists) will potentially attract a target market that offers considerable lifetime value. Despite a destination's perceived appeal, the potential perceived risks may outweigh the interest in experiencing the activities at a destination (Deng and Ritchie, 2018; Fuchs and Reichel, 2011) and a safer or more familiar destination (Hsieh et al., 2016; Pizam et al., 2004) may be of greater interest.

The purpose of this study is fourfold. First, this study seeks to determine the activity types that a target market (students) would choose to participate in when vacationing at a chosen destination. Second, students' interest in the destination will be identified. Third, students' perceived physical risk of the destination is considered for a destination that offers considerable physical risk. Fourth, this study will seek to determine whether perceived risk mediates the students' activities and interest relationship.

\section{Literature review}

\section{Activity preferences}

The opportunity for tourists to experience activities outside of their usual lifestyle and surroundings represents a key driver for destination visitation (Morrison, 2013; Prebensen, 2005). Destination activities are closely affiliated with travel motivation (Pesonen, 2015; Moscardo et al., 2001) and identifying these desired activities will enable tourism marketers to promote specific destination attributes that can be used to satisfy the needs or wants of a tourist (Morrison, 2013). Motivation is usually described in terms of initiating actions that will guide behavior, whereas preferences are portrayed as being linked to destination choice (Goodall, 1991). Consequently, identifying activity preferences prior to destination visitation will facilitate DMOs in determining what activities are desirable among potential tourists (Tkaczynski and Prebensen, 2012).

While certain activities such as hiking (Field, 1999; Pesonen, 2015), sightseeing (Arlt, 2006; Nogawa et al., 1996) and museum visitation (Lehto et al., 2012; Moscardo et al., 2001) may be popular across destinations, certain activities will not appeal to all tourists based on a wide variety of factors such as tourists' age, interest, life stage, income levels and travel party composition. Consequently, activity-based segmentation has been employed to profile tourists into groups based on particular activities for target marketing and positioning purposes. Pesonen (2015) profiled users of three Finnish rural tourism websites and classed respondents into water activities, passives, nature activities, winter activities or active segments. Lehto et al. (2012) determined seven key factors for family vacation and cohesion in a US study. These included city interests, shopping, dining and entertainment, active nature pursuits, family social events, outdoor skill-based sports and farm-based activities. McKercher et al. (2002) segmented cultural tourists to Hong Kong and labeled them as cultural generalists, icon culturalists, Chinese heritage culturalists, cultural tourists, colonial culturalists or Sino-colonial culturalists.

\section{Perceived physical risk}

Tourists' prime concern is to travel to a destination to satisfy their need for travel, with limited threats to their health, safety and well-being (Bierman, 2003; Blake and Sinclair, 2003). Potential perceived risks (e.g. long-term injury, death, sickness) resulting from natural disasters (e.g. tornadoes), hygiene (e.g. pollution), terrorism (e.g. security threats), transport (e.g. aeroplane flights) or participating in strenuous activities (e.g. extreme sports) have been identified as major deterrents to destination visitation (e.g. Chew and Jahari, 2014; Hsu and Lin, 2006). While post-disaster recovery marketing strategies have been designed by DMOs (Walters and 
Mair, 2012; Walters et al., 2015) and activities such as rock climbing and skydiving may not be chosen by some tourists, certain perceived physical risks such as natural disasters (e.g. tornadoes and hurricanes) or political unrest cannot be removed. Rather the potential impact be minimized through planning and notification of safety precautions and/or the dissemination of information through various media platforms before, during or after a potential risk (Walters and Mair, 2012).

In examining the perceived physical risk of Greece as a tourism destination, Mitchell and Vassos (1998) determined 43 risk factors as perceived by British and Cypriot undergraduate students. Ritthchainuwat and Chakraborty (2009) recognized terrorism, increase in travel costs, lack of novelty seeking, disease, deterioration of tourist attractions and travel inconvenience as the six perceived risk factors for international tourists visiting Thailand. Nagai and Tkaczynski (2014) identified three physical risk factors, disorder, hygiene and impairment, as perceived among international students studying in Australia. Adam (2015) concluded a high rate of road accidents, natural disasters and physical assault as relevant perceived physical risks of backpackers visiting Ghana.

\section{Interest}

Despite a destination's competitive resource appeal, tourists may also not choose to have a vacation at this location. Reasons for this avoidance could include a lack of interest, high financial cost and the tyranny of distance (i.e. long-haul travel). While measuring the activities that tourists choose to experience at a destination is usually done by researchers post experience (Lehto et al., 2012; McKercher et al., 2002), it is argued that people's perceptions and attitudes in addition to their past experience can predict future behavior (Ajzen and Fishbein, 1980). Research can therefore be conducted with potential segments prior to impending travel to identify the level of interest among tourists in a destination and to understand the activities that are preferred. For example, Tkaczynski and Prebensen (2012) identified the nature-based motivational preferences that French residents had when considering Norway as a tourism destination. Similarly, Leisen (2001) determined the image of New Mexico as a vacation destination as perceived by non-residents of eight states in the United States. Hsieh et al. (2016) recognized that
Taiwanese youth studying at various universities in Taiwan had different levels of interest in choosing a vacation in Japan.

\section{Student travel}

From a tourism perspective, the importance of the student market can be attested to the increasing number of university students engaged in vacation breaks (Thrane, 2016; WYSE Travel Confederation, 2015). Student travel represents a unique market cohort that is distinguishable based on its motivations, travel patterns and activity preferences (Richards and Wilson, 2004; Xiao et al., 2015). For example, Pearce and Son (2004) determined that in comparison to backpackers, English-language student travelers were more likely to travel in a large group, stay in a hotel or motel and be interested in citybased travel activities. Similarly, it was concluded based on research conducted across eight different countries that student travelers showed a greater propensity to immerse themselves in cultural activities or to learn a new language when compared to youth travelers (Richards and Wilson, 2004).

Several pioneering studies (e.g. Field, 1999; Gallarza and Saura, 2006) have been conducted which highlight why students are motivated to experience different activities at different destinations. More recently, Bicikova (2014) segmented 412 British student travelers and identified four distinct clusters of sunseekers, sightseers, in-betweeners and clubbers. Hughes et al. (2015) examined the preferences and perceptions of Chinese students towards Australian tourism products. The authors determined that while costs, distance and time were the key barriers to travel, personal safety was a key concern in traveling to natural environments in Australia.

Thrane (2016) recognized that student tourists defined as 'open' returners stay longer on their trips than the 'prefixed ones'. Mohsin et al. (2017) determined the motives of young Thai university students towards holidaying. The authors concluded that experiencing new cultures, scenic values and adventure are positively related to travel interest. Deng and Ritchie (2018) identified four main risk factors, human induced, social-psychological, financial and health, as perceived by international university students studying at an Australian university. 


\section{Japanese inbound tourism}

Japan as a tourism destination has become increasingly competitive since the $1990 \mathrm{~s}$ (Cooper, 2005). In 2003, the Visit Japan Campaign was launched by the Japanese government, which aimed to increase the number of international tourists to 10 million by 2010 (Japan National Tourism Office, 2009). Although the initial figures were strong, only $8,611,175$ inbound tourists visited Japan in 2010 (Japan National Tourism Organization, 2015b). It was concluded that the negative effects of the influenza A (H1N1) and high fuel surcharges may have limited tourist numbers in 2010 (World Tourism Organization, 2012).

Although it was predicted that the undesirable effects of the twin disasters of an earthquake and a tsunami in 2011 may have limited further inbound Japanese tourism (World Travel \& Tourism Council, 2012), Japan received $10,363,904$ international tourists in 2013, which was the first time that the country received more than 10 million international tourists in its history (Japan National Tourism Organization, 2015 b). Guided by its strong cultural and natural resources such as its 21 United Nations Educational, Scientific, and Cultural Organization (UNESCO) world heritage sites, many festivals and exhibitions and creative industries, Japan was ranked as the fourth most competitive tourism destination in the world in 2017 (UNESCO, 2017; World Economic Forum, 2017). The Japanese government has also actively promoted the country as a tourism destination after the 2011 earthquake. In addition, the government developed guidelines for protecting international tourists from natural disasters and introduced services to provide the latest disaster and safety information to international tourists such as a multilingual mobile application (Japan Tourism Agency, 2014). Although Japan received around $5,200,000$ international tourists in 2003, more than 24,000,000 international tourists visited the country in 2016 with the majority traveling from Asia such as South Korea, China and Taiwan. Australia was ranked seventh as a source market, with 445,200 tourists (Japan National Tourism Organization, 2016, 2017). Overall figures indicated that the number of Japanese inbound tourists has dramatically increased in the past few years. In addition, tourism is now recognized as one of the major pillars of the nation's growth strategy and regional vitalization by the central government. The government now aims to receive 40 million international tourists by 2020, and 60 million by 2030 (Japan Tourism Agency, 2016).

Several academic studies have recently been published that have examined tourists' interest in traveling to Japan. The results indicate Japan's competitiveness as a tourism destination has been largely influenced by the potential variation in respondents' perceived physical risks that could be experienced through natural or manmade disasters. Hsieh et al. (2016) measured Taiwanese students' travel intentions to Japan. It was concluded that negative attitudes caused by potential perceived risks greatly impacted students' willingness to consider Japan as a travel destination. Of interest, students with past experience were less likely to have their travel intentions inhibited. Ji et al. (2016) identified that Chinese tourists experienced mixed feelings of resistance, admiration, welcome, embarrassment and attachment to Japan and its people. Kim and Park (2016) classified Koreans into one of four groups: non-constraint, non-negotiable, less negotiable and more negotiable based on their willingness to visit Japan due to respondents' varying perceived danger of visiting the country after the earthquake, tsunami and nuclear accident in Fukushima in 2011.

\section{Conceptual framework}

Student travel represents a growing source of income for many international destinations (World Tourism Organization, 2016; WYSE Travel Confederation, 2015). In addition to being time rich, having unique travel preferences and travel patterns (Richards and Wilson, 2004; Xiao et al., 2015), it is also argued (e.g. ITB Berlin, 2016; World Tourism Organization, 2016) that young tourists (e.g. students) are continually traveling for tourism purposes regardless of political unrest and health issues, as these tourists want to experience traveling and understand the world in the face of these issues.

Although research has identified students' interest (e.g. Hsieh et al., 2016; Ji et al., 2016), the desired destination activities they wish to experience (Bicikova, 2014; Hughes et al., 2015) and the perceived physical risks that may be incurred by students at a destination (Mitchell and Vassos, 1998; Rittichainuwat and Chakraborty, 2009), limited academic research (e.g. Hsieh et al., 2016; Park et al., 2016) has aimed to identify how perceived physical risk may or may not impact on a student's interest or 


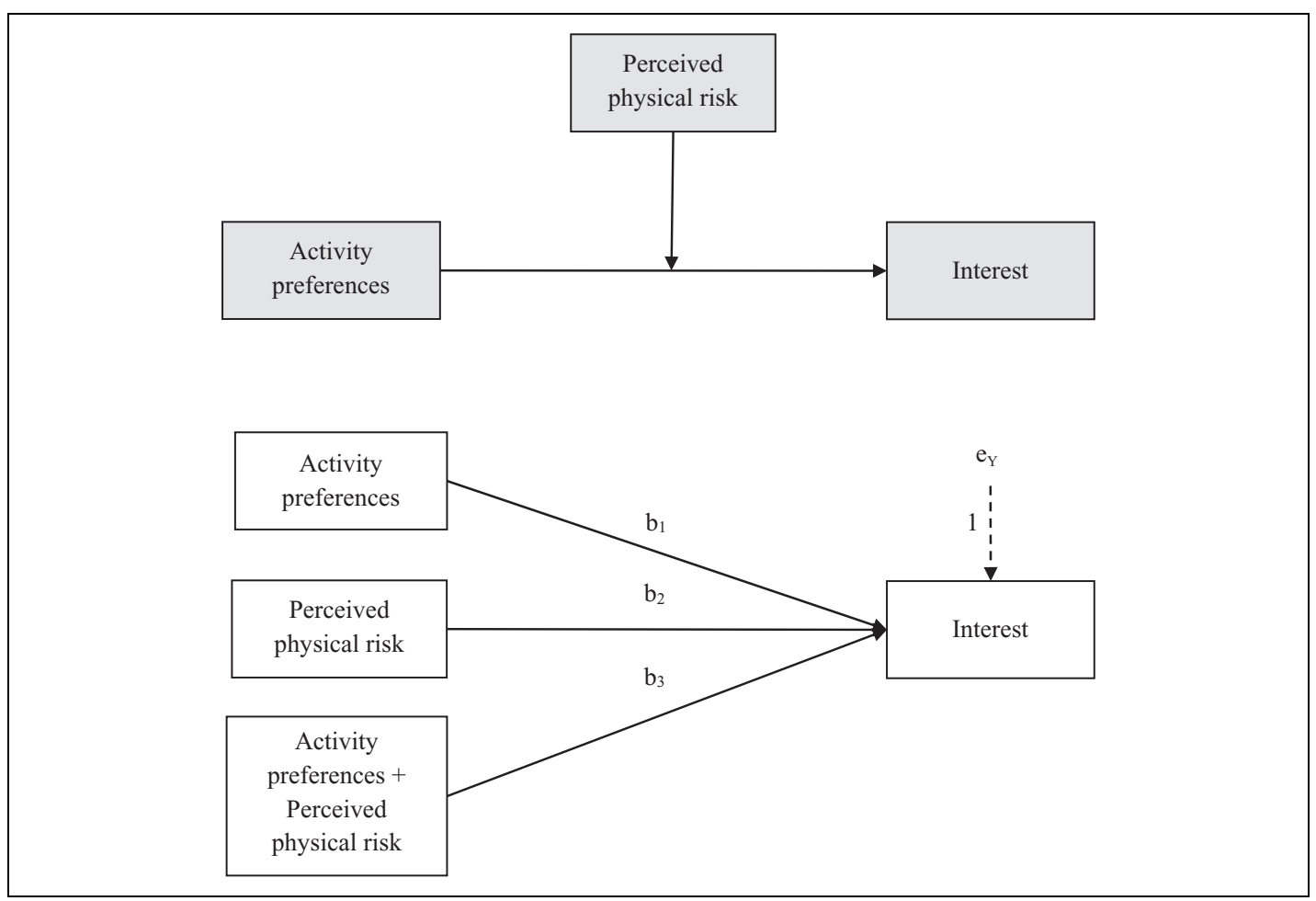

Figure I. Conceptual model: Australian students' activity preferences, perceived physical risk and interest in vacationing in Japan.

visitation at an activity-orientated destination. This gap in the literature is an impetus to this study.

In this study, Japan was chosen as the destination. Despite considerable research into Japanese domestic tourism (Arlt, 2006; Creighton, 1995), Japanese outbound tourism (Jang et al., 2004; Watkins and Gnoth, 2007) and a current drive by the government to promote Japan as a tourism destination (Japan Tourism Agency, 2015), academic research into Japanese inbound tourism has only become prominent recently (Chew and Jahari, 2014; Ji et al., 2016; Kim and Park, 2016). While several studies have measured Asian students' travel intentions and interest in vacationing in Japan (Hsieh et al., 2016; Park et al., 2016), Australia as a student source market has largely been neglected, despite the country representing a key source market for Japan. Further, although previous research (Field, 1999) has identified that Australians travel extensively during semester breaks, limited research has analysed their interest in vacationing at international destinations. Rather, the majority of research has emphasized international students' perception of Australia as a vacation destination (Son and Pearce, 2005; Waitt, 1996).

To determine Australian students' activity preferences, perceived physical risk and interest in Japan as a vacation destination, a proposed model is presented in Figure 1. The research will employ perceived physical risk as a mediator between activity preferences (independent variables) and interest (dependent variable). When perceived physical risk is combined with activity preferences, the mediating effect of perceived physical risk can be determined.

Japan's cultural activities have traditionally made it attractive for tourists (Hsu and Lin, 2006; Yamamura, 2015). However, segmenting tourists based on one dominant activity such as cultural events can exclude potentially attractive offerings unknown to DMOs that may be desired by tourists (Ashwell, 2015; McKercher et al., 2002). Marketing on one or two activities will also not accurately identify the different interest levels of potential variation in the cohort which might be based on student nationality (e.g. Australian). Hypothesis 1 determines whether the tourism activities influence Australian students' interest in vacationing in Japan. Potential rather than actual behavior is justified based on the previous argument that perceptions and attitudes in addition to past travel behavior, that is, previous vacations, can predict future behavior (Ajzen and Fishbein, 1980). 
H1: Activity preferences significantly influence students' interest in vacationing in Japan.

Perceived physical risk may limit a target market's (e.g. students) interest in experiencing activities that a destination has to offer. For example, potential injury and health concerns have been acknowledged as relevant travel barriers to Australians when considering the Middle East as a vacation option (Chien et al., 2016; Sharifpour et al., 2014). Conversely, the perception that a destination has limited physical risks may enable tourists to travel to and participate in activities at the destination (Adam, 2015; Reisinger and Mavondo, 2005). Students have a high propensity for risk-taking that involve physical interaction (Fuchs, 2013; Pizam et al., 2002, 2004) and are learning to live with fear, being 'part of life' (Lupton and Tulloch, 2002). Consequently, while certain segments (e.g. elderly, family orientated) may deem a destination physically unsafe, the student market may not be inhibited by potential physical risks.

Perceived physical risk-taking behavior influences tourists' willingness to visit a destination (e.g. Hsieh et al., 2016; Sharifpour et al., 2014). However, identifying perceived physical risk that intervenes between a potential tourist's visitation to a destination and the activities they wish to experience (e.g. culture, built attractions) is unknown. There is the potential that perceived physical risk is not an inhibitor for students' interest in visiting a destination to experience its activities, considering their resilient and adventurous nature. Consequently, it is imperative to identify whether perceived physical risk affects Australian students' interest in visiting Japan, directly, indirectly or not at all. Through employing a mediation process (Baron and Kenny, 1986) that has been frequently adopted within the tourism literature (e.g. Sharifpour et al., 2013, 2014), this study will determine whether perceived physical risk directly or indirectly influences Australian students' interest in visiting Japan. Therefore, hypotheses 2 and 3 are listed below.

H2: Perceived risk significantly influences Australian students' interest in vacationing in Japan.

H3: Perceived risk mediates Australian students' choice of activity and interest in vacationing in Japan.

\section{Methodology}

A 29-item, self-administered, questionnaire was designed based on a review of the tourism literature, Japanese promotional material and government documentation. Twenty-four activity items frequently employed within the literature (McKercher et al., 2002; Tkaczynski and Prebensen, 2012) and within the Japanese marketing material (e.g. Japan National Tourism Organization, 2015a) were chosen. An additional activity item 'other' was utilized to allow students to provide an item that may have been of personal relevance to them, not already provided within the questionnaire. In line with previous studies (Oh, 1999; Savinovic et al., 2012; Žabkar et al., 2010), a holistic outcome item (interest) was employed to measure students' intention to vacation in Japan. This procedure would enable Australian students to disclose their interest in visiting Japan as a country, rather than their interest in experiencing individual activities that may or may not be available at different Japanese locations (e.g. Tokyo, Osaka or Niseko).

Three risk items were determined from Nagai and Tkaczynski's (2014) previous research into students' perceived risk in vacationing in Japan. Similar to the literature, each psychographic item (e.g. activities, interest, risk) was measured on a seven-point Likert-type scale to maximize variation in responses (Nagai and Tkaczynski, 2014; Watkins and Gnoth, 2005). Several additional variables (e.g. age, past trip experience) were also provided for classification purposes and were designed as categorical.

The sample comprised Australian students currently enrolled at a large Australian university located in Brisbane, Queensland, Australia. This university has a high ratio of international to domestic students. Australian tourists represent an important source market for Japan (Japan National Tourism Organization, 2015b). In 2015, there were 376,075 Australian inbound Japanese tourists, with the largest segment aged between 21 and 29 (males $18.0 \%$, females $14.6 \%$ ). Several Australian-based studentorientated travel agencies such as Student Travel Association (STA) Travel and Global Student Tours design-specific packages ranging from 7 to 14 days for Australian students aged from 12 to 39. Activities promoted include experiencing big cities (sightseeing) in locations such as Tokyo, Kyoto and Osaka; hot springs in Hakone and Kusatsu; and skiing holidays in Niseko, 
Table I. Demographic information $(N=422)$.

\begin{tabular}{|c|c|c|c|c|c|}
\hline Item & Mean & SD & Item & $\mathrm{n}$ & $\%$ \\
\hline Interest & 5.18 & 1.62 & Age & & \\
\hline Activity & & & $<2$ I & 336 & 79.6 \\
\hline Explore big cities & 6.14 & 1.38 & $2 I-25$ & 62 & 14.7 \\
\hline Skiing/snowboarding & 6.01 & 1.46 & $26+$ & 23 & 5.5 \\
\hline Authentic Japanese cuisine & 5.69 & 1.50 & Education [current] & & \\
\hline Hot springs & 5.57 & 1.43 & Undergraduate & 400 & 94.8 \\
\hline Nightlife & 5.44 & 1.65 & Postgraduate & 22 & 5.2 \\
\hline Historic sites & 5.32 & 1.51 & Gender & & \\
\hline Cultural events/festivals & 5.29 & 1.43 & Male & 135 & 32.0 \\
\hline Theme parks & 5.22 & 1.79 & Female & 285 & 67.5 \\
\hline Traditional Japanese beverages & 4.95 & 1.79 & \multicolumn{3}{|c|}{ Previous experience [touring Japan] } \\
\hline Meet local people & 4.90 & 1.57 & Yes & 91 & 21.6 \\
\hline Water-based activities & 4.98 & 1.77 & No & 331 & 87.4 \\
\hline Hiking & 4.60 & 1.74 & \multicolumn{3}{|l|}{ Trip intentions [visiting Japan] } \\
\hline Live sports match & 4.58 & 1.85 & Within I year from now & 62 & 14.7 \\
\hline Luxury boat cruise & 4.57 & 1.92 & More than I year from now & 345 & 81.6 \\
\hline Extreme sports & 4.54 & 1.99 & \multicolumn{3}{|c|}{ Travel party composition [for trip to Japan] } \\
\hline Zoos/aquariums & 4.52 & 1.80 & Myself & II & 2.6 \\
\hline Traditional Japanese custom & 4.48 & 1.80 & Partner/spouse & 331 & 78.4 \\
\hline Museum visits & 4.06 & 1.68 & Family & 23 & 5.5 \\
\hline Farms/countryside & 3.99 & 1.68 & Friends & 112 & 26.5 \\
\hline Spiritual meditation retreat & 3.87 & 1.93 & Partner + family + friends & 74 & 17.5 \\
\hline Cycling & 3.38 & 1.65 & Family + friends & 63 & 14.9 \\
\hline Fishing & 3.15 & 1.83 & Family + friends + package & 18 & 4.3 \\
\hline Visiting friends and relatives & 2.97 & 2.23 & Other & 19 & 10.7 \\
\hline Medical tourism & 2.44 & 1.63 & & & \\
\hline Other & 4.19 & 2.75 & & & \\
\hline \multicolumn{6}{|l|}{ Perceived physical risk } \\
\hline Hygiene & 3.41 & 1.80 & & & \\
\hline Illness & 3.18 & 1.73 & & & \\
\hline Disability & 2.68 & 1.86 & & & \\
\hline
\end{tabular}

Hakuba and Nozawa (Global Student Tours, 2017; STA Travel, 2017a).

A convenience sampling approach was applied where students enrolled in various courses were asked to complete the questionnaire at the end of class. The students then handed their completed, anonymous response to the data collector when leaving the lecture theatre. To qualify for inclusion in the study, a respondent needed to be Australian and also knowledgeable of Japan as a tourism destination. The questionnaires were collected between March and April 2015.

\section{Data analysis}

\section{Exploratory factor analysis and regression}

Exploratory factor analysis in SPSS version 22.0 was employed using a principal components analysis with oblimin rotation. Costello and Osborne's (2005) procedure was followed. For convergent validity to be confirmed, 0.4 was utilized as a factor loading cut-off point. Crossloading items that had a factor loading $>0.4$ on another factor were removed to ensure discriminant validity. Factors that included less than three items were also eliminated (Carmines and Zeller, 1979).

Three different models estimated via multiple regression were employed. In each case, the significance levels, explained variance and $t$ values were evaluated. To ensure that multicollinearity was not an issue, items needed to correlate with each other at $<0.7$ (Tabachnick and Fidell, 2001). To answer hypothesis 1, interest in vacationing in Japan was regressed against activity preference factors. Interest was then regressed against illness, disability and hygiene to fulfil hypothesis 2 . Next, to provide a solution for hypothesis 3 , each perceived physical risk item and the defined factors were entered into the regression equation separately to examine whether risk influenced interest in travel to Japan. 
Table 2. Activity factors (segments).

\begin{tabular}{|c|c|c|c|c|c|}
\hline & Cultural & Outdoor & Excitement & Built attractions & Personal \\
\hline & Factor I & Factor 2 & Factor 3 & Factor 4 & Factor 5 \\
\hline Cultural events/festivals & 0.806 & & & & \\
\hline Historical sites & 0.753 & & & & \\
\hline Traditional Japanese custom & 0.732 & & & & \\
\hline Museum visits & 0.662 & & & & \\
\hline Meet local people & 0.622 & & & & \\
\hline Authentic Japanese cuisine & 0.539 & & & & \\
\hline Hot springs & 0.477 & & & & \\
\hline Spiritual meditation retreat & 0.414 & & & & \\
\hline Extreme sports & & 0.696 & & & \\
\hline Hiking & & 0.629 & & & \\
\hline Water-based activities & & 0.618 & & & \\
\hline Cycling & & 0.608 & & & \\
\hline Farms and countryside & & 0.531 & & & \\
\hline Skiing/snowboarding & & 0.458 & & & \\
\hline Nightlife & & & 0.707 & & \\
\hline Explore big cities & & & 0.658 & & \\
\hline Live sports match & & & 0.558 & & \\
\hline Traditional Japanese beverages & & & 0.555 & & \\
\hline Theme parks & & & & -0.768 & \\
\hline Luxury boat cruise & & & & -0.678 & \\
\hline Zoos/aquariums & & & & -0.612 & \\
\hline Medical tourism & & & & & 0.671 \\
\hline Visiting friends and relatives & & & & & 0.563 \\
\hline Fishing & & & & & 0.494 \\
\hline Eigenvalue & 5.49 & 3.17 & 1.88 & 1.52 & 1.18 \\
\hline$\%$ of variance explained & 22.87 & 13.22 & 7.86 & 6.32 & 4.9 \\
\hline Factor $\alpha$ & 0.811 & 0.704 & 0.633 & 0.676 & 0.591 \\
\hline
\end{tabular}

\section{Results of stage I}

In total, 422 surveys were collected and analysed. Missing data were minimal $(<5 \%)$ and surveys that were incomplete (e.g. demographic data not completed) or had several (e.g. three or more) of the activity items missing were removed prior to analysis to improve validity. Australian students were interested in vacationing in Japan $(\mu=5.18)$. Exploring big cities $(\mu=$ 6.18), skiing/snowboarding $(\mu=6.01)$ and tasting authentic Japanese cuisine $(\mu=5.69)$ were the most popular activities preferred. Perceived physical risks [hygiene $(\mu=3.41)$, illness $(\mu=$ $3.18)$ and disability $(\mu=2.68)]$ were rated at the lower end of the seven-point scale. The majority of respondents were under 21 years of age, female, studying an undergraduate degree and had not previously vacationed in Japan. Students traveling with friends and family and likely to travel within 1 year from now (March 2015; Table 1).

The 24 activity items were factor analysed. The other item was removed from the analysis as no dominant additional item was identified by students. The Kaiser-Meyer-Olkin was 0.832 and Bartlett's test of sphericity was significant $\left[\chi^{2}(276)=2836.568, p<0.001\right]$, which suggested that the data were appropriate for factor analysis (Carmines and Zeller, 1979). The correlation matrix produced a scale $\alpha$ of 0.848 which is above the recommended 0.7 level for exhibiting the inter-item correlation (Nunnally, 1978).

Five factors were extracted (see Table 2). Construct validity was confirmed, with all items having a loading score of 0.4 on only one factor (Tabachnick and Fidell, 2001).

The first factor $(\alpha=0.811)$ was labeled as cultural as all factor items related to cultural activities that represent traditional Japan. The second factor $(\alpha=0.704)$ was interpreted as outdoor as these six activities are usually undertaken outside by tourists with some form of physical exertion for maximum enjoyment.

The third factor is related to entertainment. Entertainment ( $\alpha=0.633)$ included activities that could be deemed exciting and engaging to the targeted Australian audience such as exploring big cities, tasting traditional Japanese 
Table 3. Multiple regression.

\begin{tabular}{lc}
\hline & \multicolumn{1}{c}{ Dependent variable } \\
\cline { 2 - 2 } Independent variables & Interest \\
\hline Cultural & $0.372(8.183)^{* *}$ \\
Outdoor & $-0.008(-0.175) \mathrm{NS}$ \\
Excitement & $0.328(7.156)^{* *}$ \\
Built attractions & $0.099(2.146)^{*}$ \\
Personal & $0.110(2.369)^{*}$ \\
Model fit information & \\
$\quad$ Multiple $R$ & 0.542 \\
$R^{2}$ & 0.293 \\
$\quad$ Adjusted $R^{2}$ & 0.283 \\
$F$ value & $29.456^{* *}$ \\
\hline
\end{tabular}

Note: Activity preferences as independent variables. The reported values are standardized $\beta$ coefficients. The values in parentheses are $t$ values. NS, not significant. $*_{p}=0.00$ : significant level.

$*_{p}<0.05$ : significant level.

beverages (e.g. sake) and experiencing the Japanese nightlife. The fourth factor $(\alpha=0.676)$ was labeled as built attractions to provide activities for potential tourists. Finally, personal is the name of the final factor $(\alpha=0.591)$. Activities such as medical tourism and fishing may be perceived as individual pursuits and personal to a particular tourist. These factors are therefore not shared with Australian students in a similar way to the group-based activities identified within the first factor.

\section{Results of stage 2}

When interest in vacationing in Japan was employed as the dependent variable (see Table $3)$, the model was highly significant $(p=0.000)$ and the five activity factors explained almost a third $(29.3 \%)$ of variance in interest to travel to Japan. It can be determined that because cultural
( $p=0.000)$, excitement $(p=0.000)$, built attractions $(p=0.033)$ and personal $(p=0.018)$ were statistically significant, these four activity types contributed strongly towards an interest in traveling to Japan. Examination of standardized coefficients indicated that cultural (0.372 [8.183]) and excitement (0.328 [7.156]) had the largest influence on interest in traveling to Japan. For every one point increase in each of cultural and excitement, a related 0.3 increase in travel to Japan was evident. Outdoor ( $p=0.861>0.05$ ) was not statistically significant, indicating these activities were not related to interest in traveling to Japan. Consequently, the first hypothesis can be partially supported.

With the three perceived physical risk items employed as independent variables, it was concluded that the explained variance was incredibly minimal for all items (hygiene the highest at $6.3 \%$ whereas the other two were under $1 \%$ ). Only hygiene $(p=0.00)$ significantly contributed (and negatively) to interest $(-2.54$ $[-5.332])$ in vacationing in Japan. Illness $(p=$ $0.070>0.05)$ and disability $(p=0.416>0.05)$ were both insignificant and, consequently, hypothesis 2 can only be partially supported (Table 4).

When each perceived risk item was combined with the five activity preference factors (see Table 5), it was concluded that the contributed variance $(29.3 \%)$ was the same for all three items. Additionally, illness $(p=0.949>0.05)$, hygiene $(p=0.952>0.05)$ and disability $(p=$ $0.945>0.05)$ all produced an insignificant relationship with interest in vacationing in Japan when combined with the five activity factors. The significance of the four activity factors also remained similar to the initial model (Table 3). Consequently, the third hypothesis was not supported.

Table 4. Multiple regression.

\begin{tabular}{lccc}
\hline & \multicolumn{3}{c}{ Independent variables } \\
\cline { 2 - 4 } & Illness & Hygiene & Disability \\
\hline Interest & $-0.089(-1.818) \mathrm{NS}$ & $-2.54(-5.332)^{* * *}$ & $-0.416(-0.814) \mathrm{NS}$ \\
Multiple $R$ & 0.089 & 0.254 & 0.040 \\
$R^{2}$ & 0.008 & 0.064 & 0.002 \\
Adjusted $R^{2}$ & 0.006 & 0.062 & -0.001 \\
$F$ value & $3.304 \mathrm{NS}$ & $28.435^{* *}$ & $0.663 \mathrm{NS}$ \\
\hline
\end{tabular}

Note: Perceived physical risk items as independent variables The reported values are standardized $\beta$ coefficients. The values in parentheses are $t$ values. NS, not significant.

$* * p=0.00$ : significant level.

$*_{p}<0.05$ : significant level. 
Table 5. Multiple regression.

\begin{tabular}{|c|c|}
\hline & Dependent variable \\
\hline \multicolumn{2}{|l|}{ Model I } \\
\hline Independent variables & Interest \\
\hline Cultural & $0.372(8.064)^{* *}$ \\
\hline Outdoor & $-0.008(-0.177) \mathrm{NS}$ \\
\hline Excitement & $0.328(7.092)^{* *}$ \\
\hline Built attractions & $0.099(2.144)^{*}$ \\
\hline Personal & $0.110(2.355)^{*}$ \\
\hline Activity_illness & $0.003(0.64) \mathrm{NS}$ \\
\hline \multicolumn{2}{|l|}{ Model fit information } \\
\hline Multiple $R$ & 0.542 \\
\hline$R^{2}$ & 0.293 \\
\hline Adjusted $R^{2}$ & $0.28 I$ \\
\hline$F$ value & $24.479 * *$ \\
\hline \multicolumn{2}{|l|}{ Model 2} \\
\hline Independent variables & Interest \\
\hline Cultural & $0.372(8.102)^{* *}$ \\
\hline Outdoor & $-0.008(-0.176) \mathrm{NS}$ \\
\hline Excitement & $0.328(7.109)^{\text {*** }}$ \\
\hline Built attractions & $0.099(2.144)^{*}$ \\
\hline Personal & $0.110(2.357)^{*}$ \\
\hline Activity_hygiene & $0.003(0.60) \mathrm{NS}$ \\
\hline \multicolumn{2}{|l|}{ Model fit information } \\
\hline Multiple $R$ & 0.542 \\
\hline$R^{2}$ & 0.293 \\
\hline Adjusted $R^{2}$ & $0.28 I$ \\
\hline$F$ value & $24.479 * *$ \\
\hline \multicolumn{2}{|l|}{ Model 3} \\
\hline Independent variables & Interest \\
\hline Cultural & $0.372(8.054)^{* *}$ \\
\hline Outdoor & $-0.008(-0.178) \mathrm{NS}$ \\
\hline Excitement & $0.328(7.096)^{* *}$ \\
\hline Built attractions & $0.099(2.144)^{*}$ \\
\hline Personal & $0.110(2.357)^{*}$ \\
\hline Activity_disability & $0.003(0.69) \mathrm{NS}$ \\
\hline \multicolumn{2}{|l|}{ Model fit information } \\
\hline Multiple $R$ & 0.542 \\
\hline$R^{2}$ & 0.293 \\
\hline Adjusted $R^{2}$ & 0.281 \\
\hline$F$ value & $24.479 * *$ \\
\hline
\end{tabular}

Note: Physical perceived risk as a mediating variable. The reported values are standardized $\beta$ coefficients. The values in parentheses are $t$ values. NS, not significant.

${ }^{* *} p=0.00$ : significant level.

$*_{p}<0.05$ : significant level.

\section{Discussion and conclusions}

Student travel represents a growing segment (World Tourism Organization, 2016; WYSE Travel Confederation, 2015) which has great importance to popular student vacation countries (and regions) such as Peru and Ecuador (Latin America), Thailand and Cambodia (Asia) and Fiji and New Zealand (South Pacific) (STA Travel, 2017b). This study contributes to the literature, focusing upon key drivers (e.g. activity preferences and interest) and inhibitors (e.g. perceived physical risk) of Australian students to Japan, an increasingly attractive tourist destination for international students (STA Travel, 2017b).

The study confirmed that tourists (e.g. students) are heterogeneous in their activity choice (Moscardo et al., 2001; Pesonen, 2015) and highly rated several of the preferred activities. Exploring big cities which can constitute sightseeing and shopping has consistently been found to be a popular tourism activity in a plethora of studies (Finsterwalder and Laesser, 2013; McKercher et al., 2002) was also relevant to this study. Australian student-orientated travel agencies such as STA Travel and Global Student Tours should continue to promote these activities in their marketing material.

Furthermore, while Australian snowboarding/ skiing participation in the international market is relatively small, which has been largely neglected (Dickson and Faulks, 2007), interest in ski resorts such as Niseko of young Australians has increased (SkiJapan, 2013), and Japan's ski locations such as Niseko, Hakuba and Myoko are heavily promoted by student travel agencies (e.g. STA Travel) as a vacation location for Australian students. As students' interest in skiing/ snowboarding has been confirmed within this study, this activity should also be emphasized within marketing material. Unsurprisingly, medical tourism and visiting friends and relatives were ranked the lowest preferred activities to experience.

Through employing activity-based segmentation, this study confirmed five activity types. Based on empirical evidence and the fact that the average tour to Japan lasts between seven and 14 days (e.g. STA Travel, 2017a; Global Student Tours, 2017), the Japanese tourism market should promote the first four activity types to Australian students to deliver a range of different experiences across potential one- or two-week vacations. These factors drive international student segment's interest in visiting Japan. Foreign cultural activities are popular to experience generally (McKercher et al., 2002) and within Japan (Ryu et al., 2015). Culture is also identified as Japan's key competitive strength (World Economic Forum, 2017) and cultural activities such as historic sites and cuisine are focused on Japanese marketing communication material such as DMO websites and social network sites such as Pinterest (Song and Kim, 2016). As Australian students were interested in historical sites (e.g. 
shrines, temples), traditional Japanese customs (e.g. tea ceremony, Kimono traditional dress) and cultural events (e.g. anime, rock concerts), these activities which are currently promoted for the upcoming 2017/2018 vacation period (STA Travel, 2017a) need to be continually focused on within marketing materials designed by Japanese DMOs, student-orientated travel agencies (e.g. STA Travel, Student Flights) and additional tourism marketers in order to continually attract this important source market.

Australian students have an interest in outdoor activities which are currently promoted within Japan (Japan National Tourism Organization, 2015a). Organizations such as Kumutu (adventure tourism), Niseko Ski Holidays, STA Travel and the Japanese government should further promote these desired activities to Australia to potentially create a larger market. Excitement and built attractions as activities currently exist in big cities such as Tokyo and Osaka and these need to be promoted to stimulate interest in Japan as a tourist destination. Activities such as nightlife, exploring big cities and drinking traditional Japanese beverages (e.g. sake) are also desired by Australian students due to these activities potentially representing a unique cultural experience.

A further contribution from this research is that perceived physical risks were largely irrelevant in influencing Australian students' interest in visiting Japan. This contradicts Nagai and Tkaczynski's (2014) earlier findings that Asian students studying in Australia highly rated these perceived physical risks. Asian countries are proximal and the largest source markets for Japan and these tourists may be aware of the difficulties that Japan faced during the 2011 disasters such as the earthquake and tsunami in 2011. In this study, lack of importance of perceived physical risks provides literature support (e.g. Reisinger and Mavondo, 2005; Reisinger and Turner, 2000) that a country's culture can increase or decrease a tourist's motivation or perceived risk in visiting a destination. The low-risk rating supports Lupton and Tulloch's (2002) argument that Australians are adventurous and perceive risk as part of everyday life. Taken together, the results of the current study and the Nagai and Tkaczynski (2014) study indicate that understanding of perceived risk cannot be assumed, rather it must be established for each inbound tourism market.

While Japan may be perceived as a 'safe' destination due to limited political unrest, terrorism or unhygienic conditions, this destination will continue to face potential natural disasters such as earthquakes and tsunamis which are deemed unpredictable and hazardous (Hewitt, 1997; Ulmer et al., 2015). Consequently, Japanese tourism marketers need to monitor these potential disasters and communicate effectively and efficiently to tourists through different promotional mediums such as tourism websites and social media when natural disasters arise (Ketter, 2016; Walters and Mair, 2012).

The role of perceived risk in the activity preference and destination interest relationship was examined. The results of the current study indicate that perceived risk was not significant in the activity preference and destination interest relationship. This presents a unique contribution to the research, as many studies (Mitchell and Vassos, 1998; Rittichainuwat and Chakraborty, 2009) have identified risk as a major inhibitor to travel. When perceived risk is examined concurrently with activity preferences to understand the interest in traveling to a destination for a segment that will deliver high value over time, the role of risk in tourist decision-making is diminished. Consequently, when DMOs in Japan are marketing to Australia, the different types of activities can be maximized within the promotional material and any perceived risks can be deemphasized in communication materials. Rather, the thrill of experiencing outdoor (e.g. skiing/ snowboarding) activities is expected to further entice Australians to visit Japan.

\section{Limitations and opportunities for future research}

This study is not without its limitations. This study is based on potential rather than actual visitation to Japan. Therefore, respondents' level of interest and potential likelihood of participating in preferred activities might not be accurate. However, research (Ajzen and Fishbein, 1980) suggests that perceptions and attitudes as well as previous experiences can influence future behavior. Planned behavior has also been recently employed to measure respondents' likelihood in visiting an international destination (Hsieh et al., 2016; Park et al., 2016). To provide further validity, it is recommended that the Australian students be targeted within a couple of years to identify whether their activity preferences, interest and perceived physical risks have changed when considering vacationing in Japan. This will determine whether visitation is likely to 
happen as expected and will also indicate whether these physiographic variables remain constant or have changed over the extended time period.

A second limitation is that the data were only collected at one Australian university (where the chief researcher was employed) which limited the generalizability of the research findings. To improve the generalizability, it is recommended that researchers from a variety of Australian universities in different states (e.g. Queensland, Victoria and New South Wales) collaborate to test the research instrument across different contexts and with different students in a follow-up study. Here the results from the additional study will identify whether the results from the initial study can be confirmed or denied.

A third limitation is that while the sample is representative in that the majority of domestic students studying at an Australian university are female (ABS, 2016), two-thirds of the sample is females which is higher than the average (approximately 56\%). As research indicated that males aged between 21 and 29 represented the largest cohort of Australian inbound tourists for Japan, future research could be conducted where a quota sampling technique is employed to ensure that a high percentage of males complete the survey.

While this study has provided initial findings in understanding the perceived physical risks such as injury and sickness that have been identified as relevant for students in past research (e.g. Nagai and Tkaczynski, 2014), an opportunity for future research is to consider affective elements in influencing students' destination choice. While cognitive elements are essential for the initial consideration of a destination (Alcañiz et al., 2009; Xie and Lee, 2013), the affective considerations will become operational during the evaluation stage of a destination selection process. Should positive affective elements (e.g. happiness, relaxing) outweigh the negatives (e.g. fear, anxiety), a tourist will be more likely to consider the destination as a potential location for a vacation (Pike and Ryan, 2004).

A final limitation deals with the measurement of interest. A final consideration is that interest was measured in the current study using a single item. Use of a single item is not unusual within the tourism literature (e.g. behavioral intentions) (e.g. Chen, 2008; Oh, 1999; Savinovic et al., 2012). An opportunity for future research exists. Specifically, research is recommended to extend the understanding of interest using a multi-dimensional item to provide a more nuanced understanding of the relationship between activity types and interest. Here it is necessary to determine the activities that are currently promoted in the sevenor 14-day tourism package and which are the most popular for Australian students when considering vacationing in Japan.

\section{Declaration of conflicting interests}

The author(s) declared no potential conflicts of interest with respect to the research, authorship, and/or publication of this article.

\section{Funding}

The author(s) received no financial support for the research, authorship, and/or publication of this article.

\section{References}

ABS (2016) 6227.0 - Education and Work, Australia, May 2016. Canberra, Australia: Australian Bureau of Statistics.

Adam I (2015) Backpackers' risk perceptions and risk reduction strategies in Ghana. Tourism Management 49: 99-108.

Ajzen I and Fishbein M (1980) Understanding Attitudes and Predicting Social Behavior. Englewood Cliffs, NJ: Prentice-Hall.

Alcañiz EB, García IS and Blas SS (2009) The functional-psychological continuum in the cognitive image of a destination: a confirmatory analysis. Tourism Management 30: 715-723.

Arlt WG (2006) Thinking through tourism in Japan. Tourism and Hospitality Planning \& Development 3: 199-207.

Ashwell J (2015) Going bush? Factors which influence international tourists' decisions to travel to remote Australian destinations. Tourism Management 46: 80-83.

Baron RM and Kenny DA (1986) The moderatormediator variable distinction in social psychological research: conceptual, strategic, and statistical considerations. Journal of Personality and Social Psychology 51: 1173-1182.

Beedie P and Hudson S (2003) Emergence of mountain-based adventure tourism. Annals of Tourism Research 30: 625-643.

Bicikova K (2014) Understanding student travel behavior: a segmentation analysis of British university students. Journal of Travel \& Tourism Marketing 31: 854-867.

Bierman D (2003) United States: September 11, 2001 Terrorist Attack. The impact on American and global tourism. In: Bierman D (ed) Restoring Tourism Destinations in Crisis: A Strategic Framework 
Approach. Wallingford: CABI Publishing, pp. 43-68.

Blake A and Sinclair MT (2003) Tourism crisis management: US response to September 11. Annals of Tourism Research 30: 813-832.

Carmines EG and Zeller RA (1979) Reliability and Validity Assessment. Thousand Oaks, CA: SAGE.

Carnicelli-Filho S, Schwartz GM and Tahara AK (2010) Fear and adventure tourism in Brazil. Tourism Management 31: 953-956.

Chen C (2008) Investigating structural relationships between service quality, perceived value, satisfaction, and behavioral intentions for air passengers: evidence from Taiwan. Transportation Research $A$ 42: 709-717.

Chew EYT and Jahari SA. (2014) Destination image as a mediator between perceived risks and revisit intention: a case of post-disaster Japan. Tourism Management 40: 382-393.

Chien PW, Sharifpour M, Ritchie BW, et al. (2016) Travelers' health risk perceptions and protective behavior: a psychological approach. Journal of Travel Research 10: 1-16.

Cooper M (2005) Japanese tourism and the SARS epidemic of 2003. Journal of Travel \& Tourism Marketing 19: 117-131.

Costello AB and Osborne JW (2005) Best practices in exploratory factor analysis: four recommendations for getting the most from your analysis. Practical Assessment, Research \& Evaluation 10: 1-9.

Creighton MR (1995) Japanese craft tourism: liberating the crane wife. Annals of Tourism Research 22: 463-478.

de Wit H, Ferencz I and Rumbley LE (2013) International student mobility. Perspectives: Policy and Practice in Higher Education 17: 17-23.

Deng R and Ritchie BW (2018) International university students' travel risk perceptions: an exploratory study. Current Issues in Tourism 21: 455-476.

Dickson TJ and Faulks P (2007) Exploring overseas snowsport participation by Australian skiers and snowboarders. Tourism Review 62: 7-14.

Enright MJ and Newton J (2005) Determinants of tourism destination competitiveness in Asia Pacific: comprehensiveness and universality. Journal of Travel Research 43: 339-350.

Field AM (1999) The College student market segment: a comparative study of travel behaviors of international and domestic students at a Southeastern University. Journal of Travel Research 37: 375-381.

Finsterwalder J and Laesser C (2013) Segmenting outbound tourists based on their activities: toward experiential consumption spheres in tourism services? Tourism Review 68: 21-43.

Fuchs G (2013) Low versus high sensation-seeking tourists: a study of backpackers' experience risk perception. International Journal of Tourism Research 15: 81-92.

Fuchs G and Reichel A (2011) An exploratory inquiry into destination risk perceptions and risk reduction strategies of first time vs. repeat visitors to a highly volatile destination. Tourism Management 32: 266-276.

Gallarza M and Saura I (2006) Value dimensions, perceived value, satisfaction and loyalty: an investigation of university students' travel behaviour. Tourism Management 27: 437-452.

Gardiner S, King B and Wilkins H (2013) The travel behaviours of international students: nationalitybased constraints and opportunities. Journal of Vacation Marketing 19: 287-299.

Global Student Tours (2017) Destinations - Japan. Available at: http://www.global-tours.com.au/desti nations, Accessed July 17, 2017.

Glover P (2011) A comparison between domestic and international students' trip characteristics: evidence from an Australian university. Journal of Vacation Marketing 17: 263-274.

Goodall B (1991) Understanding holiday choice. In: Cooper C (ed) Progress in Tourism, Recreation and Hospitality Management. London: Belhaven, pp. 103-133.

Hewitt K (1997) Regions of Risk: A Geographical Introduction to Disasters. New York, NY: Taylor $\&$ Francis.

Hsieh CM, Park SH and McNally R (2016) Application of the extended theory of planned behavior to intention to travel to Japan among Taiwanese youth: investigating the moderating effect of past visit experience. Journal of Travel \& Tourism Marketing 33: 717-729.

Hsu TH and Lin LZ (2006) Using fuzzy set theoretic techniques to analyze travel risk: an empirical study. Tourism Management 27: 968-981.

Hughes K, Wang J and Shu M (2015) Exploring the travel patterns, preferences and recommendations of Chinese university students living in Australia. Journal of Hospitality and Tourism Management 23: $12-22$.

ITB Berlin (2016) ITB World Travel Trends Report 2016/2017. Berlin: ITB Berlin.

Jang S, Bai B, Hong GS, et al. (2004) Understanding travel expenditure patterns: a study of Japanese pleasure travelers to the United States by income level. Tourism Management 25: 331-341.

Japan National Tourism Office (2009) Japan tourism to launch visit Japan Year 2010 Campaign. 
Available at: http://www.au.emb-japan.go.jp/pdf/ JNTO_Media_release_Visit_Japan_Year_2010. pdf, Accessed December 8, 2015.

Japan National Tourism Organization (2015a) Adventure \& Outdoors. Available at: http://jnto.org.au/ adventure-outdoors/, Accessed March 20, 2015.

Japan National Tourism Organization (2015b) The number of international visitors to Japan by nationality/month (2003-2015). Available at: http://www.jnto.go.jp/jpn/reference/tourism_data/ visitor_trends/pdf/2013_15_tourists.pdf, Accessed March 19, 2015.

Japan National Tourism Organization (2016) Visit Japan jigyou kaishi ikou no hounichi kyakusuu no suii (2003nen-2015nen) [Number of international tourists after the launch of the Visit Japan Campaign (2003-2015)]. Available at: http://www. jnto.go.jp/jpn/statistics/marketingdata_tourists_ after_vj.pdf.

Japan National Tourism Organization (2017) 2016 Visitor arrivals and Japanese overseas travelers. Available at: http://www.jnto.go.jp/jpn/news/ press_releases/pdf/170117_monthly.pdf, Accessed July 31, 2017.

Japan Tourism Agency (2014) Providing disaster information to international tourists in Japan [Saigai ji ni okeru hounichi gaikokujin ryokousha heno jyouhou teikyou ni tuite]. Available at: http://www. mlit.go.jp/kankocho/news03_000111.html, Accessed March 19, 2015.

Japan Tourism Agency (2015) Message from commissioner. Available at: http://www.mlit.go.jp/kanko cho/en/about/message.html, Accessed March 19, 2015.

Japan Tourism Agency (2016) Tourism vision to support the future of Japan. Available at: http://www. mlit.go.jp/common/001126601.pdf, Accessed July 31, 2017.

Ji M, Li M and Hsu CHC (2016) Emotional encounters of Chinese tourists to Japan. Journal of Travel \& Tourism Marketing 33: 645-657.

Ketter E (2016) Destination image restoration on Facebook: the case study of Nepal's Gurkha Earthquake. Journal of Hospitality and Tourism Management 28: 66-72.

Kim JS and Park SH (2016) A study of the negotiation factors for Korean tourists visiting Japan since the Fukushima nuclear accident using Q-methodology. Journal of Travel \& Tourism Marketing 33: 770-782.

Lehto XY, Lin YC, Chen Y, et al. (2012) Family vacation activities and family cohesion. Journal of Travel \& Tourism Marketing 29: 835-850.

Leisen B (2001) Image segmentation: the case of a tourism destination. Journal of Services Marketing 15: 49-66.
Lupton D and Tulloch J (2002) 'Risk is part of your life': risk epistemologies among a group of Australians. Sociology 36: 317-334.

McKercher B, Ho PSY, Cros HD, et al. (2002) Activities-based segmentation of the cultural tourism market. Journal of Travel \& Tourism Marketing 12: 23-46.

Mitchell VW and Vassos V (1998) Perceived risk and risk reduction in holiday purchases: a crosscultural and gender analysis. Journal of Euromarketing 6: 47-79.

Mohsin A, Lengler J and Chaiya P (2017) Does travel interest mediate between motives and intentions to travel? A case of young Asian travellers. Journal of Hospitality and Tourism Management 31: 36-44.

Morrison AM (2013) Marketing and Managing Tourism Destinations. New York, NY: Routledge.

Moscardo G, Pearce P and Morrison A (2001) Evaluating different bases for market segmentation. Journal of Travel \& Tourism Marketing 10: 29-49.

Nagai H and Tkaczynski A (2014) Understanding perceived physical risk: the case of Japan. Tourism Analysis 19: 249-253.

Nogawa H, Yamaguchi Y and Hagi Y (1996) An empirical research study on Japanese sport tourism in sport-for-all events: case studies of a singlenight event and a multiple-night event. Journal of Travel Research 35: 46-54.

Nunnally JC (1978) Psychometric Theory. New York: McGraw-Hill.

Oh IK (1999) Service quality, customer satisfaction, and customer value: a holistic perspective. International Journal of Hospitality Management 18: 67-82.

Park SH, Hsieh CM and Lee CK (2017) Examining Chinese college students' intention to travel to Japan using the extended theory of planned behavior: testing destination image and the mediating role of travel constraints. Journal of Travel \& Tourism Marketing 34: 113-131.

Park SH, Hsieh CM and Lee CK (2016) Examining Chinese college students' intention to travel to Japan using the extended theory of planned behavior: testing destination image and the mediating role of travel constraints. Journal of Travel \& Tourism Marketing.

Pearce P and Son A (2004) Youth tourism markets in Australia: comparing the travel behaviours of international English language students and backpackers. Tourism (Zagreb) 52: 341-350.

Pesonen JA (2015) Targeting rural tourists in the Internet: comparing travel motivation and activitybased segments. Journal of Travel \& Tourism Marketing 32: 211-226. 
Pike S and Ryan C (2004) Destination positioning analysis through a comparison of cognitive, affective, and conative perceptions. Journal of Travel Research 42: 333-342.

Pizam A, Jeong G, Reichel A, et al. (2004) The relationship between risk-taking, sensation-seeking, and the tourist behavior of young adults: a cross-cultural study. Journal of Travel Research 42: 251-260.

Pizam A, Reichel A and Uriely N (2002) Sensation seeking and tourist behavior. Journal of Hospitality and Leisure Marketing 9: 17-33.

Prebensen NK (2005) Segmenting the group tourist heading for warmer weather. Journal of Travel \& Tourism Marketing 19: 27-40.

Reisinger Y and Mavondo F (2005) Travel anxiety and intentions to travel internationally: implications of travel risk perception. Journal of Travel Research 43: 212-225.

Reisinger Y and Turner L (2000) Japanese tourism satisfaction: gold coast versus Hawaii. Journal of Vacation Marketing 6, 299-317.

Richards G and Wilson J (2004) The international student travel market: travelstyle, motivations and activities. Tourism Review International 8: 57-67.

Rittichainuwat BN and Chakraborty G (2009) Perceived travel risks regarding terrorism and disease: the case of Thailand. Tourism Management 30: 410-418.

Ryu E, Hyun SS and Shim C (2015) Creating new relationships through tourism: a qualitative analysis of tourist motivations of older individuals in Japan. Journal of Travel \& Tourism Marketing 32: 325-338.

Savinovic A, Kim S and Long P (2012) Audience members' motivation, satisfaction, and intention to re-visit an ethnic minority cultural festival. Journal of Travel \& Tourism Marketing 29: 682-694.

Sharifpour M, Walters G and Ritchie BW (2013) The mediating role of sensation seeking on the relationship between risk perceptions and travel behavior. Tourism Analysis 18: 543-557.

Sharifpour M, Walters G, Ritchie BW, et al. (2014) Investigating the role of prior knowledge in tourist decision making: a structural equation model of risk perceptions and information search. Journal of Travel Research 53: 307-322.

SkiJapan (2013) Niseko ski resort in Japan. Available at: http://www.news.com.au/travel/travel-ideas/ niseko-ski-resort-in-japan/story-e6frfqdr1226728380633, Accessed March 20, 2015.

Son A and Pearce P (2005) International students' view of Australia as a tourist destination. Journal of Travel \& Tourism Marketing 18: 21-35.

Song SG and Kim DY (2016) A pictorial analysis of destination images on Pinterest: the case of Tokyo,
Kyoto, and Osaka, Japan. Journal of Travel \& Tourism Marketing 33: 687-701.

Sönmez SF and Graefe AF (1998) Determining future travel behaviour from past travel experience and perceptions of risk and safety. Journal of Travel Research 37: 171-177.

STA Travel (2017a) Asia 2017/18 - Japan: STA Travel, Accessed July 30, 2017.

STA Travel (2017b) Top destinations. Available at: http://www.statravel.com/top-destinations.htm, Accessed July 30, 2017.

Tabachnick BG and Fidell LS (2001) Using Multivariate Statistics. Boston: Allyn \& Bacon.

Thrane C (2016) Students' summer tourism: determinants of length of stay (LOS). Tourism Management 54: 178-184.

Tkaczynski A and Prebensen NK (2012) French nature-based tourist potentials to Norway: Who are they? Tourism Analysis 17: 181-193.

Ulmer RR, Sellow TL and Seeger MW (2015) Effective Crisis Communication: Moving From Crisis to Opportunity, Thousand Oaks, CA: SAGE.

UNESCO (2017) Japan - UNESCO. Available at: http://whc.unesco.org/en/statesparties/jp, Accessed July 30, 2017.

Waitt G (1996) Korean students' assessment of Australia as a holiday destination. Australian Geographer 27: 249-269.

Walters G and Mair J (2012) The effectiveness of postdisaster recovery marketing messages - the case of the 2009 Australian Bushfires. Journal of Travel \& Tourism Marketing 29: 87-103.

Walters G, Mair J and Ritchie BW (2015) Understanding the tourist's response to natural disasters: the case of the 2011 Queensland floods. Journal of Vacation Marketing 21: 101-113.

Watkins LJ and Gnoth J (2005) Methodological issues in using Kahle's list of values scale for Japanese tourism behaviour. Journal of Vacation Marketing 11: 225-233.

Watkins LJ and Gnoth J (2007) Japanese tourism values: a means-end investigation. Journal of Travel Research 50: 654-668.

World Economic Forum (2017) The Travel \& Tourism Competitiveness Report 2017: Paving the way for a more sustainable and inclusive future. Available at: http://www3.weforum.org/docs/WEF_TTCR_ 2017_web_0401.pdf, Accessed July 17, 2017.

World Tourism Organization (2012) Yearbook of Tourism Statistics, Compendium of Tourism Statistics and Fata Files. Madrid: World Tourism Organization.

World Tourism Organization (2016) Affiliate Members Global Reports- The Power of Youth Travel. Madrid: UNWTO. 
World Travel \& Tourism Council (2012) Japan's tourism economy to stage full recovery in 2012. Available at: http://www.wttc.org/news-media/ news-archive/2012/japans-tourism-economystage-fullrecovery-2012/, Accessed July 17, 2017.

WYSE Travel Confederation (2013) Youth and student travel market: Executive Summary, Accessed July 17, 2017.

WYSE Travel Confederation (2015) Millenial Traveller II. Amsterdam: WYSE Travel Confederation.

Xiao H, So KKF and Wang AY (2015) The university student travel market: motivations and preferences for activities. Tourism Analysis 20: 399-412.
Xie KL and Lee JS (2013) Toward the perspective of cognitive destination image and destination personality: the case of Beijing. Journal of Travel \& Tourism Marketing 30: 538-556.

Yamamura T (2015) Revitalization of historical heritage using pop culture in Japan: Shiroishi city and the game/anime Sengoku Basara Tourism Analysis 20: 327-332.

Žabkar V, Brenčič MM and Dmitrović T (2010) Modelling perceived quality, visitor satisfaction and behavioural intentions at the destination level. Tourism Management 31: 537-546. 